\title{
KID WITH SPEECH DELAY AND LANGUAGE COMPETENCE EMPIRIC SOLUTION
}

\author{
Ieva Kudinga \\ Distance Education Study Centre, Riga Technical University, Latvia
}

\section{Dace Ratniece}

Distance Education Study Centre, Riga Technical University, Faculty of Sciences and Engineering, Liepaja University Latvia

\begin{abstract}
The paper explains the experience and the principles, how to teach knowingly the language and constructively communication for preschool kid with delayed speech. The external environment should be mainly calm, when necessary rigidity on setting borders should be demonstrated. Playing on the feelings, when necessary and when borders not recognized by kid. The teacher and the parent should update the attitude to kid based on experience. The teacher or the parent should grow as personality during the job with kid. The external environment should be well defined and consistent. The rules and the actions and the language with the actions should be in the everyday routine. The goal of the paper is to demonstrate the language structure, the condition for kid and examples used to communicate with kid with speech delay.
\end{abstract}

Keywords: autism, attention deficit hyperactivity disorder (adhd), language, speech delay, delayed speech, hyperactivity, sensitivity, preschool age.

\section{Introduction}

The aim of the paper is to share the experience how to teach kid with speech delay language word by word and structurally. While teaching the neural links are defined in the brain. The contemplation methods, reflection and recurrence methods are used to reach the objective.

New way of thinking - or how to teach the people with special needs develop to speech consistency and harmonically.

The question is how to teach the kid to speak or to say some words using communication skills. How to grow up the communication skills. Author of this paper speaks about empiric based experience and also on the research about how the people perceive the information.

There are three types how sensitive kids perceives information. The first group of kids are photo -visual thinkers. These kids are mainly artistic oriented. The second group of kids are pattern thinkers. Mathematicians, musicians, programmers. These kids are poor readers. They need additional help in reading. If they are getting to easy tasks in maths, the learning process ends with 
behavior problems. The third group of kids are thinkers in words. In a learning process we have to develop all type of thinking, (Kennedy \& Banks \& Grandin, 2011), but we have to take notes, which is primary thinking type for the kid.

The language teaching method is not created in one day, it has been changed and updated every day based on everyday experience in 3 years period. It based also on teaching observation research methods (Albrehta, 1998). The main person or the mentor has to give the kid $100 \%$ attention, to demonstrate the initiative to be precise in giving the directions using language phrases.

This experience is based on the professional life of author - experience as programmer and as a mother. Author likes to investigate the situations herself and others in real life and take some action, modify the behavior and attitude. Author asks the question herself: "What to change in the process or myself while bringing up the person with speech delay, and then got the answer intuitively".

Little kids or either big one, who has inability to speak and to communicate the way the main people do, have the opportunity to develop it. While the parents are developing their strength to set the borders to kid. Even the kid will have not a nice, but adequate response reaction - cry 1-2 hours in the beginning.

Autists ask us to be precise and consistency and calm. The same as computer asks us to be consistency and also calm. Even he himself still is not precise and is excited. Autist asks the mentor to be an authority to be precise with him. The aim is to get feedback from autistic kid to be accurately himself. Autistic kid wants to create precise, updatable process descriptions and rules in the world with defined exceptions.

They have their own will and it is hard to convince them to hear yourself. But from the religion - from the Bible we know that we have to name the demon in the name of it, if we expect to overcome it. So the author frequently says until nowadays to the boy - „Please, hear with the ears!” and I show with my hands my ears. „Please, look at the things only with eyes!” in the shop or while we have gone visiting other people.

At the first time it looks, he does not understand or does not hear you. But it is illusion. On average he checks whether the author is faithful to your life principles - he checks if you ask others to respect your true life values.

Autistic kid asks you as a parent - will you give up your true heart values? Do you know the true values what are in the heart and not in the mind?

\section{About the precise language competence}

Author has taught some basic words - person, up, down, room, bathroom, cup etc. Later author has used the associative principles. Author had asked: "Please answer - yes or no". In the first year kids did not react. After 2 years 
author started to use - person mama or person doctor or person teacher. Author has defined many times small rules, like.

„Please, ask you - Am I allowed to do it?” After a year the kid asked something like that I understood it. I was happy. One step forward.

Author has used every day the same words: Person, Morning!, Trousers, TShirt, Socks, Breakfast, Porridge, Potatoes, Water or Juice. Jacket. It was necessary to speak briefly and precise. In every step we played the game - who is the main person.

"Please, get ready for going out!" (First year it will take some 10 minutes to be him ready.) "Please, do not that!" (Very useful phrase.) "Sorry!" (Very useful phrase, the kid like politeness.)

"You have to dress up!" (Many times should be said convincingly if he does not like.). It was very hard to get the confidence of him, so the author took the extra care for him to get the confidence of him.

Author bought some clothes, even the kid did not accept the first 5 times them. Author had announced 1 day before the kid, that she had a plan to buy clothes, it helped her. A kid started to trust her. Finally he dressed up the clothes author bought, but not all clothes. At the same time the progress has been, because author has accepted his behavior with peaceful reaction. And the kid accepted the mentor's activities.

Author regularly bought some necessary useful things (plasticine, glue stick, interesting pencil), showed how to use them.

Every day precise the same words should be used. When a kid understand this, you can extend the phrases.

After two years of individual work author started to use such structures are: "if ...., then." "First...., after." A kid did not understand the first 5 structures of course, but he tried. This is a game - who will be more assertive and more unyielding. Unyielding against your true life values.

\section{The essence of teaching language (some similarities to computer language)}

One year only nouns. Or nouns with small verbs if necessary? Nouns we use every day. Everything should be said mild or very strict.

After two years I used the structured sentences with following structure.

"At first, then"

"If, then"

"That not ... that is...."

\section{Some tips and tricks using the timeline}

The mentor have to define the jobs for the kid step by step in timeline. 
The kid should use comprehensive daily schedule that embeds the supports the student needs to be successful. In addition, the daily schedule should include the activities which continue develop the skills and the measurement of skill development. Social, communication and sensory needs should be planned and defined for support team for exactly kid. (Henry \& Miles, 2007)

"Fig. 1", "Fig. 2" Defined jobs and exceptions should be explained always before.

The mentor have to think all the time, before you do or say. You should say and explain short and precise, - you should be honest. Kid with special needs asks of you to live disciplined, effective and precise life - it means to become happy. Kid with special needs asks of you to see, accept and solve the problems immediately, if that is possible.

$\mathrm{He}$ asks you to understand that he feels more emotionally tone than physically hears the words. It means mainly to speak with him in calm tone, if not rare necessary strict tone. Otherwise you will increase their excitement.

"Fig. 1" The day should be planned and explained.

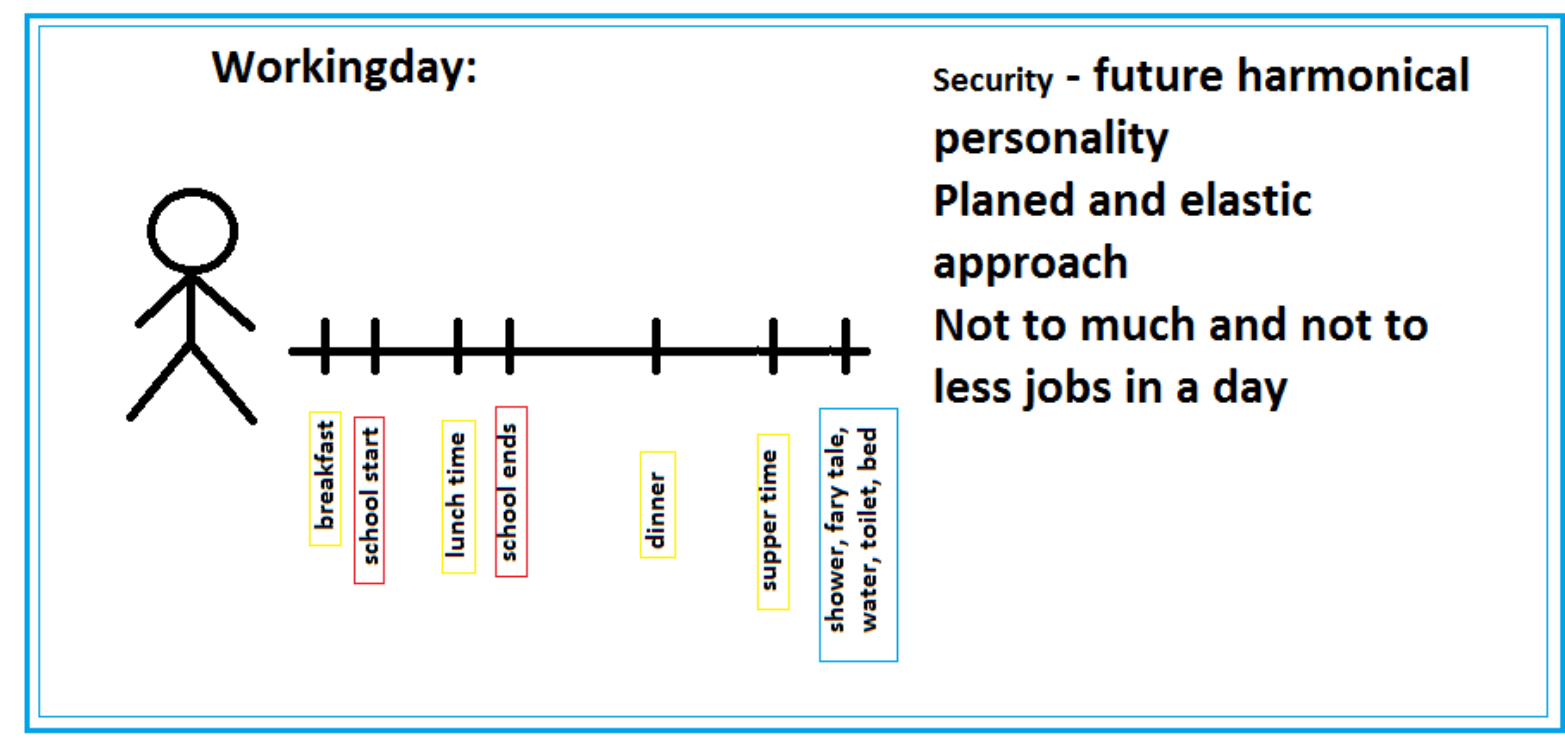

Figure 1 Planned Workingday everyday

"Fig. 2" You have to explain the kid honestly if some changes are happening in plans.

In author experience she touched 1 year long period 1 word in the sentence. Sometimes two words in the sentence. Always the same. Every day the same day. Every day in the breakfast the porridge. So a kid knows that it is a breakfast. "Juice or the water?" the author asked every day to get the answer one day. 


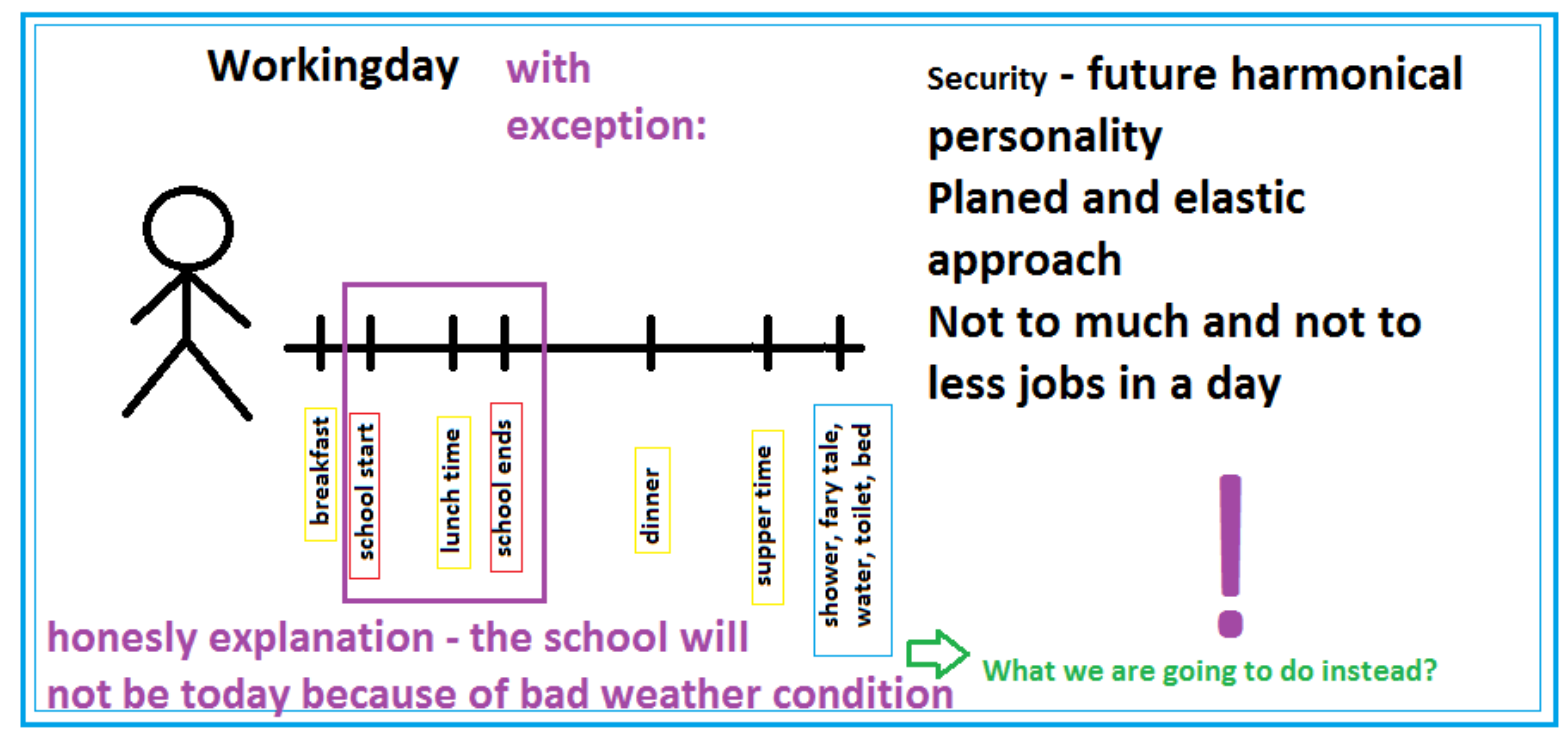

Figure 2 Planned Workingday with exceptions

Speech, language and listening develops from the birth but in different speed. Kids with language problems mainly have listening problems, because the listening process is the most common way how we get the information into brain. Also the ear and noise health problems could cause some later language expression and listening problems. Alternative communication (like PECS, BLISS) could be used to decrease the stress level of the kid (Hamaguchi, 2010).

Lot of psychological restrictions should be respected. Giving simple, but tasty food percentage high dosage and a little dosage of low value food. Creating mild and strict regulations. What did it pay to author? Needs time to be alone regularly, because kid rejected the regulations 1-2 years with an adequate shouting. What were the benefits? Author has got a mild kid in the park and shop and on the street mainly but not in the working place - home.

Working with children means enough personal, technically organized environment, psychology organized environment. Problems should be resolved in team work: parents together with teachers (Wood, 2006).

The nutrion plays significant role in developing learning disabilities, psychiatric disorders and physical problems. Probiotics are suggested to use to update digestive system. GAPS diet is recommended to clean the body systems. GAPS diet is based on SCD (the Specific Carohydrate Diet), the aim is to rebalance the immune system and to balance optimal bacterial ecosystem within the gastrointestinal tract. The diet restricts all grains, commercial dairy, starchy vegetables and all processed/refined carbohydrates (Campbell-McBride, 2010).

Structural language helps kid make some patterns in head, kid has time to understand the structured sentence. Some kids like to play with letters, so they 
recognize that some words can be divided, analyzed and created other words from them (Monsees, 1972).

We have not to focus that kid is not hearing, but we have to focus on that we have to speak with a kid shortly, precise words or sentences, every day the same. We have to focus, what author can give - not too much and not too less. A little bit progress concerning the society development and integration will be noticed after 6 months. A larger progress will be noticed after two years.

\section{Conclusions}

Based on the empirical research observation method the principles of communication teaching is developed and demonstrated. It based on a process and word repetition, beginning with nouns, then nouns with verbs concentrating with $100 \%$ on the kid. Working individually with kid, changing the methods if not working with him. Working individually with the materials found in nature and home - books, plasticine. Being polite, mild and strict. Working regularly 23 years long period. Encouraging to answer and ask many times. Even looks like he do not react first year. Accept the kid how he is but give the attitude as to a well behaved student.

The language teaching is based on structural language sentences. The structure is equal so the kid recognize what we want from him. Very often in the speech is used 1-2 words, otherwise the kid is not able to working out how to distinguish the words.

The daily routine should be defined and explained. Then the unexpected changes should be explained timely if possible. Direct and concise language should be used.

After 2-3 years period you can start to explain the complicated everyday rules. We should remember that the mentor needs to explain an autistic kid more casual and society rules, when he is ready to accept the borders and he is ready to communicate.

\section{References}

Albrehta, Dz. (1998). Pētī̌šnas metodes pedagogiijā. R., Mācību grāmata.

Campbell-McBride, N. (2010). Gut and Psychology Syndrome: Natural treatment for Autism, Dyspraxia, A.A.D, Dyslexia, A.D.H.D., Depression, Schizophrenia. Medinform Publishing.

Hamaguchi, P. M. (2010). Childhood Speech, Language, and Listening Problems. Wiley. Henry, S, \& Myles, B. S. (2007). The Comprehensive Autism Planning System (CAPS) for Individuals with Asperger syndrome, Autism and related disabilities, integrated Best Practices Throughout the Student's Day. Autism Asperger Publishing Co. 
SOCIETY. INTEGRATION. EDUCATION Proceedings of the International Scientific Conference. Volume III, May $27^{\text {th }}-28^{\text {th }}$, 2016. 79-85

Kennedy, D. M., Blanks, S. R, \& Grandin, T. (2011). Bright not Broken, gifted kids, ADHD and Autism. New York

Monsees, E. K. (1972). Structured language for children with special language learning problems.

Wood, C., Littleton, K., \& Sherry, K. (2006). Developmental psychology in action. Open University. 